\title{
Beach Sand Filtrate as an Alternative Gas Fuel
}

\author{
Hasdinar Umar ${ }^{\mathrm{a}, *}$ \\ aDepartment of Ocean Engineering, Faculty of Engineering, Universitas Hasanuddin. Email: hasdinarumar@unhas.ac.id
}

\begin{abstract}
The golden age of the oil business in Indonesia is over and now petroleum is even a burden. As oil producing countries prepare themselves to start the second phase of the golden era of oil, Indonesia is heading towards an era of energy crisis. Renewable energy is needed as an alternative to meet the community's fuel needs. Beach sand is one material that can be used to help the biomass gasification process. Small particles of sand are filled into a container and gas is flowed from below and suppresses the flow of each particle which is useful for the biomass decomposition process. When using beach sand, we can also utilize heat energy optimally in coastal areas to make gasification reactions easier. This study aims to examine the groups contained in the TMS (Tetramethylsilan) spectrum of the beach sand filtrate fluid by paying attention to the CH3 compounds which are arranged in TMS. FTIR (Fourier Transform Infrared Spectroscopy) test results show that the beach sand filtrate fluid gives an illustration that from wavelengths of 3000 to 3500 the sharpness of the amount of nitrogen and hydrogen in the sand beach filtrate liquid solution can be used as ammonia gas (a fuel). Nitrogen and Hydrogan when bound with Hydroxide will form ammonium hydroxide which can function as a fuel (heating).
\end{abstract}

\section{Introduction}

The golden age of the oil business in Indonesia was over and now it was petroleum instead it becomes a burden. Renewable energy, such as solar cells, wind power, biomass, etc. were attracting the attention of various parties, mainly because the use of these various energies did not increase concentration carbon dioxide in the air. Biomass was a potential source of energy, its use was quite varied, so it was very important. Biomass was a concept that views biota bodies quantitatively. This concept also includes agricultural products including biomass. As oil producing countries prepare to start the second golden era of oil, Indonesia was heading for an era of energy crisis [1]. The products of nanotechnology are nanomaterials, where nanosilica synthesis is currently being developed which is very widely used in the electronics field. The largest silica content is found in coastal sand [2].

One of them observed in this study is that sea sand from Lampung Province has the characteristics of coarse grains and varying gradations and has a content of chloride $(\mathrm{Cl})$ and sulfate (SO4) salts not exceeding the specified limit [3]. Previous research stated that beach sand originated from corals which had weathered and eroded turned out to have a lot of mineral and ion content, one of which is S4 (sulfate). Sulfate itself is one of the main components of the clay / red soil that we know together can be used as a catalyst in the gasification process of sawdust. With that, we can make So 4 Compound as a reference to make beach sand as a catalyst in the gasification process.

*Corresponding author. Telp.: +62-811-416-5078

Jalan Poros Malino km. 6, Bontomarannu,

Gowa, South Sulawesi, Indonesia 92171
In addition, coastal sand is mostly composed of silisium dioxide, so that it can be used as raw material for silisium production. Silisium itself in the process of processing silisium dioxide into silisium or metal materials that are gray can be used energy that is environmentally friendly and is provided by nature, namely wind energy or energy from sunlight. Silisium is a non-toxic material and has energy content such as carbon, which is the core of fossil energy. The energy in silisium is stored safely because of chemical bonds, and can be moved to other places safely. When the process of producing silisium into silicon is obtained by-product liquid, Tetramethylsilan (TMS) which has a fuel energy of gasoline from petroleum. If this TMS is burned, it will produce less energy and $\mathrm{CO} 2$ gas compared to gasoline and clean sand. Thus, this TMS can be used as an alternative fuel for the future.

The FTIR (Fourier Transform Infrared Spectroscopy) testing of Kuri Ca 'in the Maros Regency shows that beach sand has a $\mathrm{CH} 3$ group in the TSM spectrum, which proves that beach sand has fuel energy [4]. FTIR was a way of characterizing a functional group of a sample. If infrared light was passed through a sample of an organic compound, then there were a number of frequencies that were absorbed and some were transmitted or transmitted without being absorbed. The absorption of light by molecules was dependent on the electronic structure of the molecule. The molecules that absorb that energy there were changes in vibrational energy and changes in the level of rotational energy [5]. The FTIR method has the advantage of being accurate and fast, while requires minimal sample preparation even suitable for in situ analysis by using a portable FTIR spectrometer [6]. FTIR is very effective at identifying these forms of silica, 
whereas microscopy and X-ray diffraction (XRD) are still powerless to distinguishes non-crystallized forms. FTIR spectroscopy is numerous used for identification of silica forms [7].

\section{Experimental Setup}

This research was conducted at the Chemistry Department Laboratory of FMIPA Unhas.

1. Material of experiment

a) Liquid yield from the Sand filtrate

b) Natriumsulfate (Na2SO4)

2. Experimental Tool
a) Test tube (Fig. 1)
b) FTIR (Fourier-transform infrared spectroscopy) test (Fig. 3)
c) Circle plat (Fig. 2)
d) Crystal and solid $\mathrm{NaCl}$
e) Aluminium Foil

3. Experimental Process
a) Pour the liquid filtrate from the beach sand with methanol into the test tube as much as 5 drops.
b) Add 5 grams of Natriumsulfat into the test tube consisting of beach sand filtrate liquid so that the liquid in the tube can be solid.
c) Cover the test tube with aluminum foil then shake the test tube so that the filtrate solution can be fused with natriumsulfate.
d) After that the sample will be put into a circular plate mold which is coated with $\mathrm{NaCl}$ which has been dense which is useful for removing the remnants of water contained and so that infrared rays can penetrate the liquid filtrate that has been compacted.
e) Then the circular plate will be tested through the FTIR tool the content of the TSM from the white sand filtrate liquid extracted with methanol

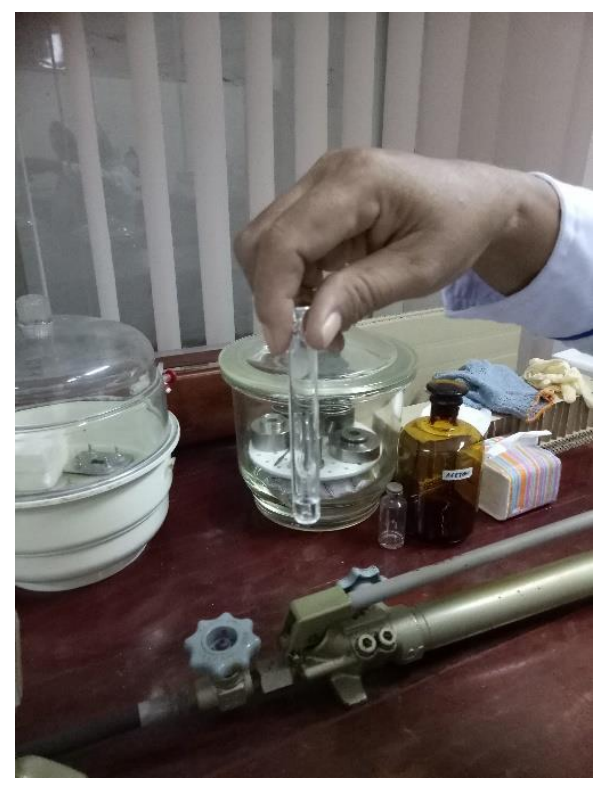

Figure 1. Test Tube

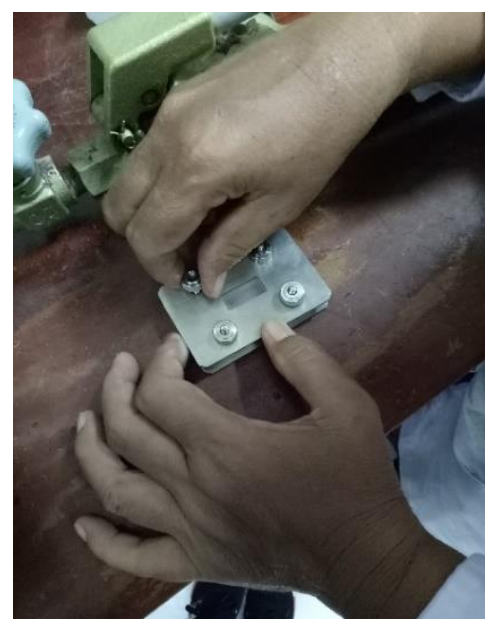

Figure 2. Sample in a Circular Plat

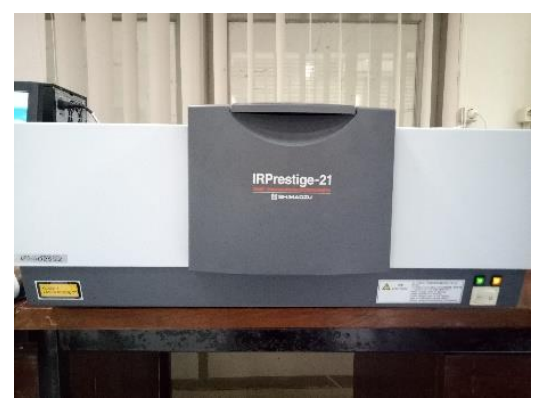

Figure 3. FTIR Test

4. How to read FTIR spectra as shown in Fig. 3.

a) Find the $\mathrm{X}$-axis and $\mathrm{Y}$-axis of the spectrum. The $\mathrm{X}$ axis of the IR spectrum was labeled as "wave number" and the numbers range from 400 on the far right to 4,000 on the far left. The $\mathrm{X}$-axis provides the absorption number. The $\mathrm{Y}$ axis was labeled as "Percent transmittance" and the numbers range from 0 at the bottom to 100 on the top.

b) Determine the characteristics of the peaks in the IR spectrum. All infrared spectrum contains many peaks. Next look at the functional group area data needed to read the spectrum.

c) Determine the region of the spectrum where the characteristic peaks were present. The IR spectrum can be separated into four regions. The first region ranges from 4,000 to 2,500 . The second region ranges from 2,500 to 2,000 . The three regions range from 2,000 to 1,500 . The fourth region ranges from 1,500 to 400 .

d) Determine the functional group absorbed in the first region. If the spectrum has a characteristic peak in the 4,000 to 2,500 range, the peaks correspond to the absorption caused by the single $\mathrm{NH}, \mathrm{CH}$ and $\mathrm{OH}$ bonds.

e) Determine the functional group absorbed in the second region. If the spectrum has a characteristic peak in the range of 2,500 to 2,000 , the peaks correspond to the absorption caused by the triple bond. 
f) Determine the functional group absorbed in the third region. If the spectrum has a characteristic peak in the 2,000 to 1,500 range, the peaks correspond to the absorption caused by a double bond such as $\mathrm{C}=\mathrm{O}, \mathrm{C}=\mathrm{N}$ and $\mathrm{C}=\mathrm{C}$. 7. Compare the peak in the fourth region to the peak in the other fourth region of the IR spectrum. The fourth was known as the fingerprint region of the IR spectrum and contains a large number of absorption peaks which account for a wide variety of single bonds. If all the peaks in the IR spectrum, including those in the fourth region, were identical to the peaks of the other spectrum, then you can be sure that the two compounds were identical.

\section{Experimental Results}

The results of the Sand Filtrate Fluid were tested using a FTIR (Fourier-transform infrared spectroscopy) tool aimed at examining how much nitrogen and hydrogen content contained in TMS is already in liquid form (Fig. 5 and Table 2). As is known that TMS (Tetramethylsilan) is a polar compound that is soluble in water and therefore the solvent used to dissolve it is methanol. Methanol is known as a semi-polar compound, which when combined with beach sand will dissolve all polar compounds contained in beach sand. When viewed from the FTIR chart prove that the wavelength of 3000 to 3500 (Table 1) shows the sharpness of the many elements of nitrogen and hydrogen in liquid solutions that can be used as ammonia (a fuel). Nitrogen and Hydrogan when bound with Hydroxide will form ammonium hydroxide which can function as a fuel (heating) as shown in Fig.4.

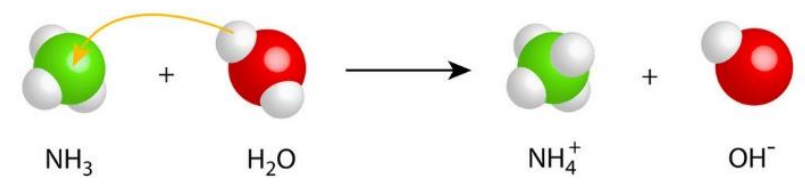

Figure 4. Chemical reaction of nitrogen and hydrogen bound with hydroxide

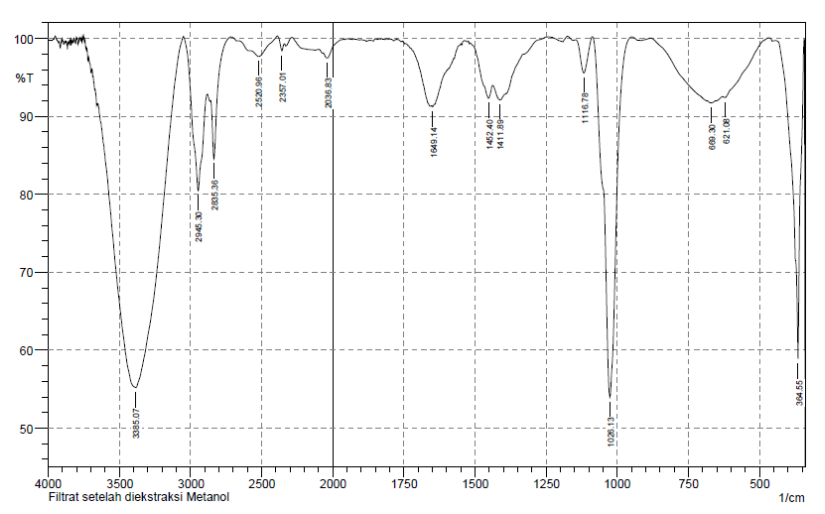

Figure 5. FTIR test result of filtration beach sand
Table 1. Functional area on IR [8]

\begin{tabular}{|c|c|c|c|}
\hline Bond & Compound Tipes & $\begin{array}{c}\text { Regional } \\
\text { Frequency }\end{array}$ & Intensity \\
\hline $\mathrm{C}-\mathrm{H}$ & Alkana & $\begin{array}{l}2850-2970 \\
1340-1470\end{array}$ & $\begin{array}{l}\text { Strong } \\
\text { Strong }\end{array}$ \\
\hline $\mathrm{C}-\mathrm{H}$ & Alkena & $\begin{array}{c}3010-3095 \\
675-995\end{array}$ & $\begin{array}{l}\text { Medium } \\
\text { Strong }\end{array}$ \\
\hline $\mathrm{C}-\mathrm{H}$ & Alkuna & 3300 & Strong \\
\hline $\mathrm{C}-\mathrm{H}$ & Cincin Aromatik & $\begin{array}{c}3010-3100 \\
690-900\end{array}$ & $\begin{array}{l}\text { Medium } \\
\text { Strong }\end{array}$ \\
\hline \multirow[t]{2}{*}{$\mathrm{O}-\mathrm{H}$} & $\begin{array}{l}\text { Fenol, Monomer } \\
\text { alcohol, alcohol } \\
\text { ikatan hydrogen, } \\
\text { fenol }\end{array}$ & $\begin{array}{l}3590-3650 \\
3200-3600\end{array}$ & $\begin{array}{c}\text { Fluctuate } \\
\text { Fluctuate } \\
\text { Sometimes it } \\
\text { widen }\end{array}$ \\
\hline & $\begin{array}{lr}\text { Monomer } & \text { asam } \\
\text { karboksilat, } & \text { ikatan } \\
\text { hydrogen } & \text { asam, } \\
\text { karboksilat } & \end{array}$ & $\begin{array}{l}3500-3650 \\
2500-2700\end{array}$ & $\begin{array}{l}\text { Medium } \\
\text { Widen }\end{array}$ \\
\hline $\mathrm{N}-\mathrm{H}$ & Amina, Amida & $3300-3500$ & Medium \\
\hline $\begin{array}{l}\mathrm{C}==== \\
\mathrm{C}\end{array}$ & Alkena & $1610-1680$ & Fluctuate \\
\hline $\begin{array}{l}\mathrm{C}==== \\
\mathrm{C}\end{array}$ & Cincin Aromatik & $1500-1600$ & Fluctuate \\
\hline $\begin{array}{l}\text { C } \Xi \Xi \Xi \\
\text { C }\end{array}$ & Alkuna & $2100-2260$ & Fluctuate \\
\hline $\mathrm{C}-\mathrm{N}$ & Amina, Amida & $1180-1360$ & Strong \\
\hline $\begin{array}{l}\mathrm{C} \\
\mathrm{N}\end{array}$ & Nitril & $2210-2280$ & Strong \\
\hline $\mathrm{C}-\mathrm{O}$ & $\begin{array}{l}\text { Alkohol, Eter, Asam } \\
\text { Karboksilat, Ester }\end{array}$ & $1050-1300$ & Strong \\
\hline $\begin{array}{l}\mathrm{C}==== \\
\mathrm{O}\end{array}$ & $\begin{array}{l}\text { Aldehid, Keton, } \\
\text { Asam Karboksilat, } \\
\text { Ester }\end{array}$ & $1690-1760$ & Strong \\
\hline $\mathrm{NO}_{2}$ & Senyawa Nitro & $\begin{array}{l}1500-1570 \\
1300-1370\end{array}$ & Strong \\
\hline
\end{tabular}

Besides the sharpness of the elements of alkenes, and alkenes in the Coastal Sand Filtrate Liquid graphs tested using FTIR (Fourier-transform infrared spectroscopy) so that compounds for fuel produced at TSM (Tetramethylsilan) will be more numerous.

\section{Conclusion}

Based on the results of testing using FTIR shows that :

a) Wavelengths of 3000 to 3500 show the sharpness of the many elements of nitrogen and hydrogen in the liquid sand beach filtrate solution which can be used as ammonia gas (a fuel).

b) The Alkene and Alkuna elements in the FTIR test chart for Sand Beach filtrate fluid are sharper, which shows that there are more fuel compounds produced at the TMS. 
Table 2. Data of FTIR test result

\begin{tabular}{cccccccc}
\hline No & Peak & Intensity & Corr.Intensity & Base (H) & Base $(\mathbf{L})$ & Area & Corr. Area \\
\hline 1 & 364.55 & 58.894 & 40.993 & 441.7 & 343.33 & 6.288 & 6.215 \\
2 & 621.08 & 92.421 & 0.498 & 628.79 & 487.99 & 2.68 & 0.245 \\
3 & 669.3 & 91.728 & 0.269 & 682.8 & 653.87 & 1.07 & 0.021 \\
4 & 1026.13 & 53.974 & 46.229 & 1085.92 & 948.98 & 11.61 & 11.73 \\
5 & 1116.78 & 95.57 & 4.459 & 1145.72 & 1087.85 & 0.54 & 0.547 \\
6 & 1411.89 & 92.112 & 2.649 & 1436.97 & 1240.23 & 2.899 & 0.629 \\
7 & 1452.4 & 92.328 & 2.569 & 1516.05 & 1438.9 & 1.54 & 0.396 \\
8 & 1649.14 & 91.212 & 0.443 & 1653 & 1573.91 & 1.991 & 0.002 \\
9 & 2036.83 & 97.489 & 0.116 & 2040.69 & 1957.75 & 0.426 & -0.052 \\
10 & 2357.01 & 98.412 & 1.248 & 2389.8 & 2339.65 & 0.146 & 0.105 \\
11 & 2520.96 & 97.688 & 1.289 & 2574.97 & 2389.8 & 1.039 & 0.535 \\
12 & 2835.36 & 84.543 & 8.697 & 2856.58 & 2717.7 & 3.161 & 1.13 \\
13 & 2945.3 & 80.487 & 15.119 & 3049.46 & 2883.58 & 7.923 & 5.315 \\
14 & 3385.07 & 55.215 & 40.229 & 3651.25 & 3051.39 & 84.967 & 73.908 \\
\hline
\end{tabular}

\section{Acknowledgements}

The authors would like to thank to LP2M Universitas Hasanuddin for the grant of PDPA 2019, Chemical Laboratory, Faculty of Science, Universitas Hasanuddin and Coastal Engineering and Environmental Laboratory, Department of Ocean Engineering, Faculty of Engineering, Universitas Hasanuddin.

\section{References}

[1] Indirasardjana, Pria. 2014. 2020 Indonesia Dalam Bencana Krisis Minyak Nasional. Jakarta: Gramedia.

[2] Alimin et.al, 2016, Analisis Kandungan Mineral Pasir Pantai Losari Kota Makassar Menggunakan XRF dan XRD, CHEMICA: Jurnal Ilmiah Kimia dan Pendidikan Kimia, Vol. 17 No. 2, 2016.
[3] Fuad, I.S. 2015, The Effect of Using River Sand with Sea Sand Against the Press Strength and Bending of Concrete Quality K-225. Journal of Technology Desimination, Volume 3 No. 1, January 2015 Palembang: Civil Engineering Study Program, Faculty of Engineering, University of Tridinanti.

[4] H.Umar, et.al, 2019, The Content and Function of Electrical Energy Sources from Silisium which are contained by the Sand of Kuri Ca'di Beach in Maros Regency. J. Phys : Conf. Ser, 1341052002.

[5] Soleh, Mohamad. 2014. Ekstrasi Silika dari Sekam Padi dengan Metode Pelarutan dan Pengendapan Silika serta Analisis EDX dan FTIR [skripsi]. Bogor: Institut Pertanian Bogor.

[6] Gil, M.I.A., Luna, M., Zarzuela, R., \& García-Moreno, M.V 2020 , 'Quantitative Determination of the Penetration of a Silica-Based Consolidant in a Limestone by FTIR Spectroscopy', Vibrational Spectroscopy, vol. 110, doi: 10.1016/j.vibspec.2020. 103109.

[7] Salih and Zaher, 2019, Investigation of silica polymorphs stratified in siliceous geode using FTIR and XRD methods, Material Chemistry and Physics 228, Elsevier, 2019

[8] Skoog, et.al, 1998, Principles of Instrument Analysis, Saunders College Pub, 1998. 